\title{
Perancangan Aplikasi Skripsi Online Menggunakan Algoritma String Matching Knuth Morris-Pratt Pada Fakultas Teknik Universitas Islam Sumatera Utara \\ ${ }^{(1)}$ Arief Rahman Hakim, ${ }^{(2)}$ Khairuddin Nasution, ${ }^{(3)}$ Oris Krianto Sulaiman, ${ }^{(4)}$ Mhd. Zulfansyuri Siambaton \\ (1)(2)(3)(4) Universitas Islam Sumatera Utara
}

Email : ${ }^{(1)}$ ariefrahmanh1@gmail.com $\left.{ }^{(2}\right)$ Khairuddin_nst@uisu.ac.id ${ }^{(3)}$ oris.ks@ft.uisu.ac.id ${ }^{(4)}$ zulfansyuri@ft.uisu.ac.id

\begin{abstract}
Abstrak
Aplikasi Skripsi Online ini bertujuan untuk menyimpan Koleksi skripsi-skripsi yang ada di Universitas Islam Sumatera Utara dalam bentuk file elektronik dan didistribusikan sehingga dapat diakses dan dibaca secara online oleh pengunjung namun tidak dapat dicopy filenya. Sistem ini memiliki fasilitas perekaman aktifitas user untuk mengetahui statistik pengunjung, skripsi yang sering dibaca, statistic browser yang digunakan user dan halaman-halaman yang diakses user serta memiliki fasilitas pencarian cepat dan pencarian detail bagi user. Artikel membahas tentang cara perancangan dan implementasi Algoritma String Matching Knuth Morris-Pratt pada Aplikasi Skripsi Online yang mampu menangani penyimpanan file-file skripsi pada server dalam bentuk Portable Document format (PDF) yang dirubah kedalam bentuk Flipbook yang menggunakan bantuan Turn Js sebagai tool dalam pembuatan tampilan flipbook. Sistem ini dikembangkan menggunakan PHP, MySql, dan HTML5. Hasil yang diperoleh adalah sebuah Aplikasi Skripsi Online berbasis Web yang bertampilkan flipbook yang dapat membantu pengelolaan perpustakaan didalam mengelola skripsi-skripsi digital, mengetahui halaman yang diakses pengunjung, skripsi yang sering dibaca, dan mengetahui statistik pengunjung. Serta dapat memberi informasi mengenai skripsi digital yang ada dan membantu pengunjung perpustakaan didalam mencari dan membaca skripsi digital secara online.
\end{abstract}

Kata Kunci : skripsi, flipbook, String Matching Knuth Morris-Pratt

\begin{abstract}
This Online Thesis application aims to save a collection of theses at the Islamic University of North Sumatra in the form of electronic files and distributed so that they can be accessed and read online by visitors but cannot be copied files. This system has a facility to record user activities to find out visitor statistics, theses that are read frequently, browser statistics used by users and pages accessed by users, and has a fast search facility and detailed search for users. The article discusses how to design and implement Knuth Morris-Pratt String Matching Algorithm in the Online Thesis Application that is able to handle the storage of thesis files on the server in the form of Portable Document format (PDF) which is converted into Flipbook form using Turn Js as a tool in making flipbook display. This system was developed using PHP, MySql, and HTML5. The results obtained are a Web-based Online Thesis Application that features a flipbook that can help library management in managing digital theses, knowing which pages visitors are visiting, theses that are often read, and knowing visitor statistics. And can provide information about existing digital thesis and help library visitors in finding and reading digital thesis online.
\end{abstract}

Keywords: thesis, flipbook, String Matching Knuth Morris-Pratt

\section{Pendahuluan}

Perkembangan Teknologi Informasi memang sangat cepat dan jauh berbeda dengan masa awal kehadirannya. Kini Teknologi Informasi, dengan sumber daya yang disebut dengan Web, telah banyak digunakan oleh berbagai organisasi untuk mendukung kelancaran kegiatan. Dari sekedar menangani penyampaian informasi sampai ke penyelenggaraan bisnisnya sendiri. 
Web sangat banyak digunakan dilingkungan pengguna internet, karena kemudahan yang diberikan kepada Internet untuk melakukan penelusuran, dan pencarian informasi. Suatu situs Web akan dikenal dengan cepat apabila informasi yang disajikan selalu up to date dan lengkap.

Kebutuhan akan informasi yang akurat dan tepat waktu untuk menyajikan data-data yang lengkap sangat diperlukan oleh suatu instansi, organisasi dan perusahaan. Sistem Informasi memberikan banyak keuntungan bagi penggunanya, yaitu kecepatan dan ketepatan dalam melakukan proses pencarian dan pengolahan data ( Sutarman, 2003).

Skripsi adalah suatu bentuk karya ilmiah yang disusun oleh setiap mahasiswa atas dasar suatu penelitian dalam rangka menyelesaikan studi program strata satu (S1).

Turn.js, adalah sebuah library javascript yang fungsinya hampir sama dengan FlashPageFlip, namun tanpa flash. Turn.js menggunakan teknologi HTML5 dan CSS3, terutama dibagian efek membuka halaman buku. Turn js bisa dijalankan di browser seperti chrome 16, safari 5, internet explorer dan juga firefox 10. Turn.js akan membuat konten anda terlihat seperti buku atau majalah asli yang menggunakan semua keunggulan HTML5. Web semakin cantik dengan antar muka pengguna baru berbasis HTML 5, turn js paling cocok untuk tampilan majalah, buku,ataupun katalog yang berbasis di HTML 5.

Algoritma string matching adalah suatu metode yang digunakan untuk menemukan suatu keakuratan atau hasil dari suatu atau beberapa pola teks yang diberikan. String matching merupakan pokok bahasan yang penting dalam ilmu komputer, karena teks merupakan bentuk utama dari pertukaran informasi antar manusia, misalnya pada literature, karya ilmiah, halaman web dan sebagainya .

Saat ini di lingkungan Universitas Islam Sumatera Utara, proses pengumpulan skripsi masih menggunakan metode manual dimana mahasiswa harus mencetak skripsi tersebut, banyak sekali kekurangan dengan menggunakan pengumpulan skripsi secara manual, salah satunya tidak ada penyimpanan skripsi yang baik karena skripsi tercetak. Oleh sebab itu dengan mengganti skripsi tersebut menjadi digital akan membuat penyimpanan skripsi menjadi terstruktur dan lebih baik. Hal itu dapat dilakukan dengan membuat suatu aplikasi ataupun website yang dapat mempermudah setiap orang untuk mengakses kedalam aplikasi tersebut untuk pencarian skripsi.

\section{TINJAUAN PUSTAKA}

1. Sistem Informasi

Secara umum Sistem Informasi dapat didefinisikan sebagai suatu sistem didalam suatu organisasi yang merupakan kombinasi dari orang-orang, fasilitas, teknologi, media prosedur-prosedur dan pengendalian yang ditujukan untuk mendapatkan jalur komunikasi penting, memproses tipe transaksi rutin tertentu, memberi sinyal kepada manajemen dan yang lainnya terhadap kejadian-kejadian internal dan eksternal yang penting dan menyediakan suatu dasar informasi untuk pengambilan keputusan.

Sistem Informasi dapat diartikan sebagai sebuah sistem yang terintegarsi secara optimal dan berbasis komputer yang dapat menghimpun dan menyajikan berbagai jenis data yang akurat untuk berbagai macam kebetulan. Sistem Informasi pada dasarnya terbentuk dari suatu kelompok kegiatan operasi yang tetap, yaitu :

1) Mengumpulkan data

2) Mengelompokkan data

3) Menghitung 

4) Menganalisa
5) Menyajikan laporan.

\section{Website}

Website adalah suatu halaman web yang saling berhubungan yang umumnya berisikan kumpulan informasi yang disediakan secara perorangan, klompok, atau organisasi. Sebuah situs web biasanya ditempatkan setidaknya pada sebuah server web yang dapat diakses melalui jaringan internet.

"Website atau disingkat web, dapat diartikan sekumpulan halaman yang terdiri dari beberapa laman yang berisi informasi dalam bentuk data digital baik berupa text, gambar, video, audio, dan animasi lainnya yang disediakan melalui jalur internet. Lebih jelasnya, website merupakan halaman-halaman yang berisi informasi yang ditampilkan oleh browser seperti Mozilla Firefox, Google Chrome atau yang lainnya." ( Rohi Abdulloh, 2016 ).

\section{Database}

Database adalah sekumpulan file data yang satu sama lainnya saling berhubungan yang diorganisasi sedemikian rupa sehingga memudahkan untuk mendapatkan dan memproses data tersebut. Lingkungan sistem database menekankan pada data yang tidak tergantung (independent) pada aplikasi yang akan menggunakan data tersebut. (Mukhamad Masrur, 2015).

Database (Basis Data) merupakan kumpulan dari data-data yang tersusun. Data-data tersebut dapat berupa skema, tabel, query, laporan dan objek-objek lainnya. Cara untuk mengakses data-data ini biasanya disebut dengan Database Management System (Sistem Manajemen Basis Data) yang berbentuk sebuah perangkat lunak komputer yang dimana pengguna (user) dapat berinteraksi dan mengakses terhadap semua data yang ada pada database tersebut.

\section{Algoritma String Matching}

String Matching adalah proses pencarian semua kemunculan query yang selanjutnya disebut pattern ke dalam string yang lebih Panjang. String matching dirumuskan dengan :

$$
\begin{aligned}
& x=x[0 \ldots m-1](1) \\
& y=y[0 \ldots . . n-1](2)
\end{aligned}
$$

Dimana :

$$
\begin{aligned}
& \mathrm{x}=\text { Pattern } \\
& \mathrm{m}=\text { Panjang Pattern } \\
& \mathrm{y}=\text { Teks } \\
& \mathrm{n}=\text { Panjang text }
\end{aligned}
$$

\section{Algoritma String Matching Knuth Morris Praat}

Algoritma Knuth-Morris-Praat (KMP) merupakan proses pencocokan string. Bila terjadi ketidak cocokan pada saat pattern sejajar dengan teks [i...i $+\mathrm{n}-1$ ], kita bisa menganggap ketidak cocokan pertama terjadi diantara teks $[\mathrm{i}+\mathrm{j}]$ dan pattern $[\mathrm{j}]$, dengan $<\mathrm{j}<\mathrm{n}$. Berarti, teks $[\mathrm{i} \ldots \mathrm{i}+\mathrm{j}]=$ pattern $[0 \ldots \mathrm{j}+1]$ dan $\mathrm{a}=$ teks $[\mathrm{i}+\mathrm{j}]$ tidak sama dengan $\mathrm{b}=$ pattern $[\mathrm{j}]$. 
Dengan kata lain, pencocokan string akan berjalan secara efisien bila kita mempunyai table yang menentukan berapa Panjang kita seharusnya menggeser seandainya terdeteksi ketidak cocokan di karakter ke-j dari pattern. Tabel itu harus memuat next [j] yang merupakan posisi karakter pattern [j] setelah digeser, sehingga kita menggeser pattern secara besar $\mathrm{j}$-next $[\mathrm{j}]$ relative terhadap teks.

Secara sistematis, langkah-langkah yang dilakukan algoritma Knuth-Morris-Pratt pada saat mencocokan string adalah sebagai berikut :

1. Algoritma Knuth-Morris-Pratt mulai mencocokkan pattern pada awal teks.

2. Dari kiri ke kanan, algoritma ini akan mencocokkan karakter per karakter pattern, dengan karakter di teks yang bersesuaian sampai salah satu kondisi berikut terpenuhi :

a. Karakter di pattern dan teks yang dibandingkan tidak cocok (mismatch).

b. Semua karakter di pattern cocok, kemudian algoritma akan memberitahukan penemuan diposisi ini.

3. Algoritma kemudian menggeser pattern berdasarkan table next, lalu menghitung langkah 2 sampai pattern berada di ujung teks.

Proses pencarian pada Aplikasi Skripsi Online Fakultas Teknik UISU dapat dilakukan dengan salah satu algoritma string yaitu algoritma Knuth Morris-Pratt, dimana hasil pencarian skripsi akan ditampilkan. Pada proses pencarian data dibutuhkan metode untuk pencarian string dengan menggunakan algoritma Knuth Morris-Pratt (KMP). Algoritma Knuth-MorrisPratt merupakan algoritma yang digunakan untuk melakukan proses pencocokan string. Contoh penggunaan algoritma Knuth-Morris-Pratt untuk pencarian pattern dalam teks :

Text : “APLIKASI SKRIPSI ONLINE”

Pattern : "SKRIPSI"

Contoh Pencarian Algoritma KMP

Tabel 3.2 Langkah-langkah Pencarian Algoritma String Matching Knuth Morris-Pratt

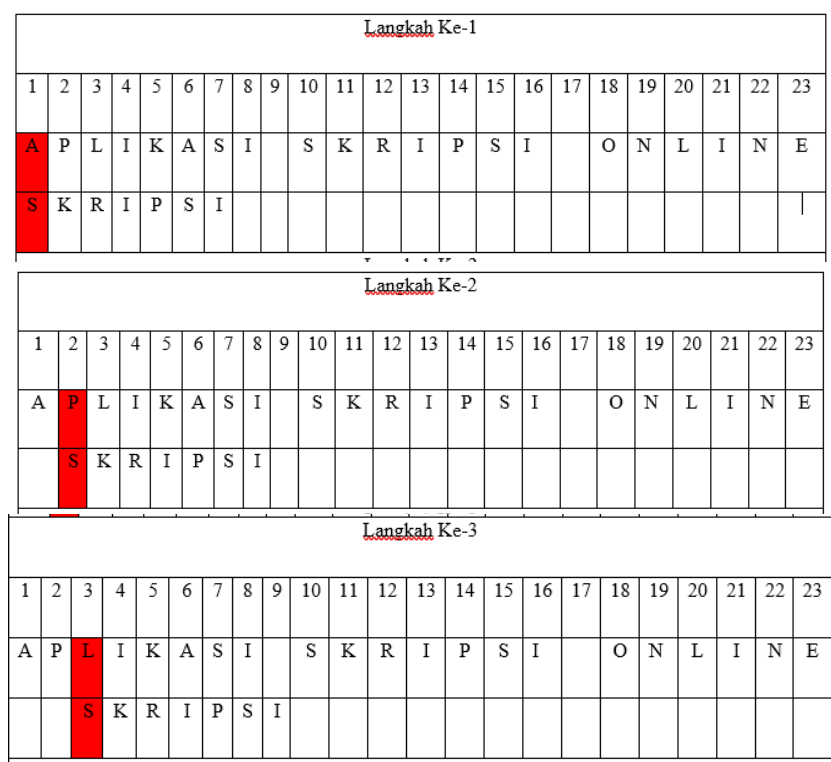




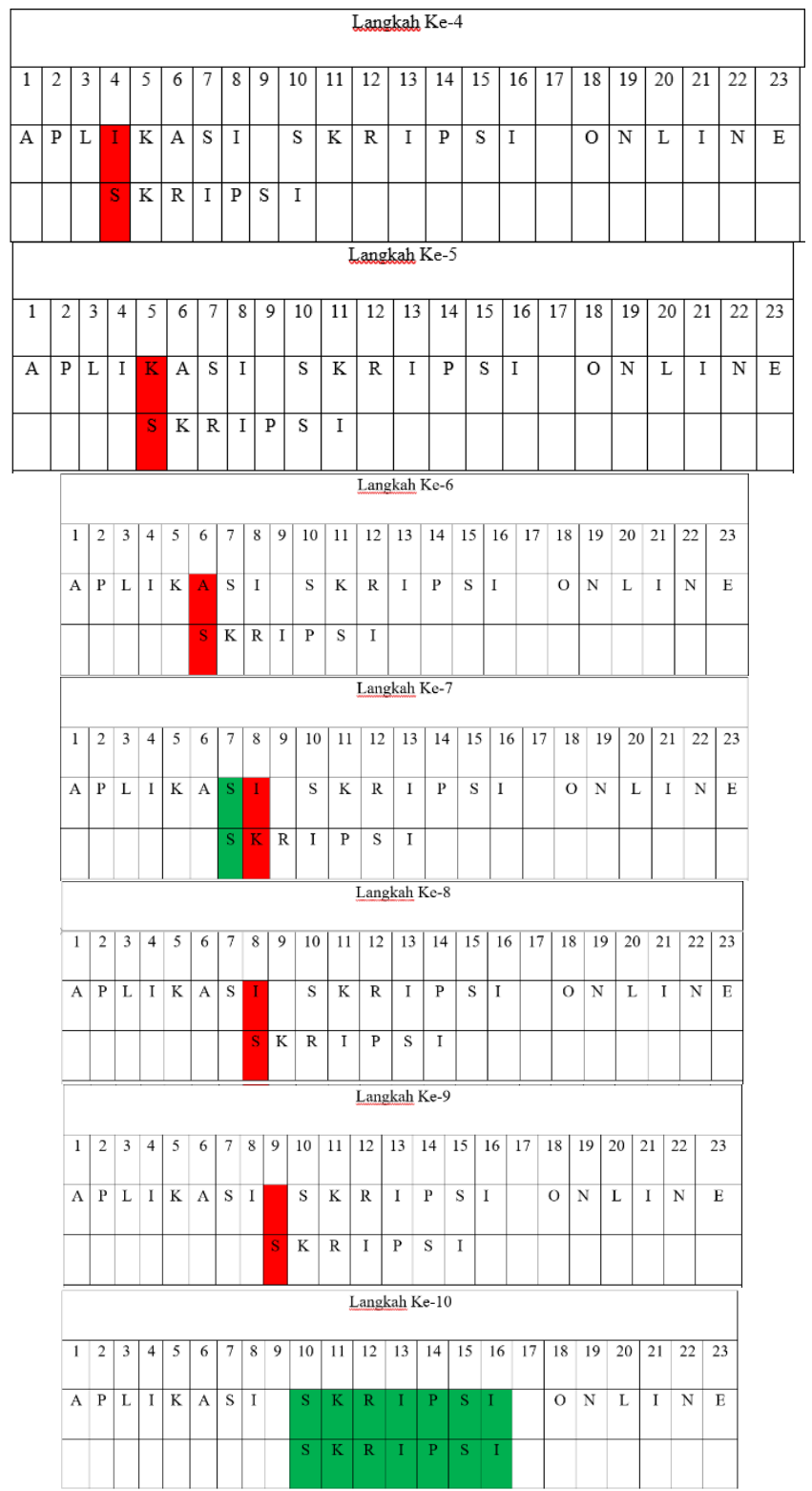

Pada tabel diatas dapat kita lihat langkah pertama text tidak cocok dengan pattern, kemudian pattern pindah ke indeks selanjutnya. Pada langkah kedua text pun tidak cocok dengan pattern, kemudian pattern pindah ke indeks selanjutnya. Kamudian pada langkah ke tujuh salah satu text cocok dengan pattern, akan tetapi text berikutnya tidak cocok, kemudian kedua pattern tersebut pindah ke indeks selanjutnya. Kemudian pada langkah ke 10 seluruh text cocok dengan pattern dan pencarian pun diberhentikan.

\section{Metodelogi Penelitian}

1. Flowchart String Matching Knuth Morris Praat 


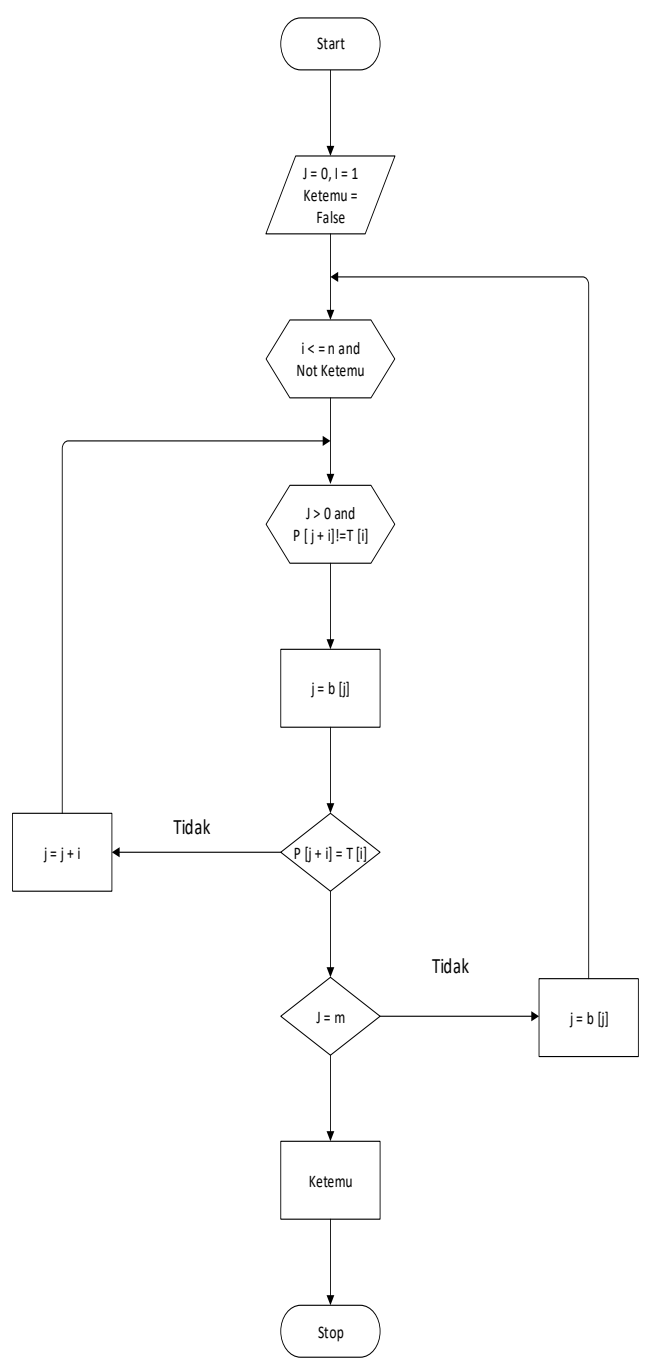

Gambar 3.1 Flowchart Pencarian Algoritma String Matching Knuth Morris Praat

Pada Flowchart tersebut dapat kita lihat Algoritma Knuth Morris Pratt mulai mencocokkan pattern pada awal teks dari kiri kekanan, algoritma ini akan mencocokkan karakter per karakter pattern dengan karakter di teks yang bersesuaian, sampai salah satu kondisi terpenuhi dimana Karakter di Pattern dan di teks yang dibandingkan tidak cocok (mismatch) dan juga Semua karakter di pattern cocok. Kemudian algoritma akan memberitahukan penemuan posisi ini. Algoritma kemudian menggeser pattern berdasarkan tabel next, lalu mengulangi langkah-langkah sampai pattern berada diujung teks.

Jika semua huruf pada pattern sudah dicocok kan dengan string maka akan ditemukan sebuah pola kosa kata didalam string. Dalam menemukan sebuah pola pattern didalam string akan dilakukan pergeseran beberapa kali untuk mencocokkan setiap huruf pada pattern yang dimulai dari sebelah kiri untuk mencocokkan setiap huruf pada string. 
2. Flowchart Perancangan Aplikasi

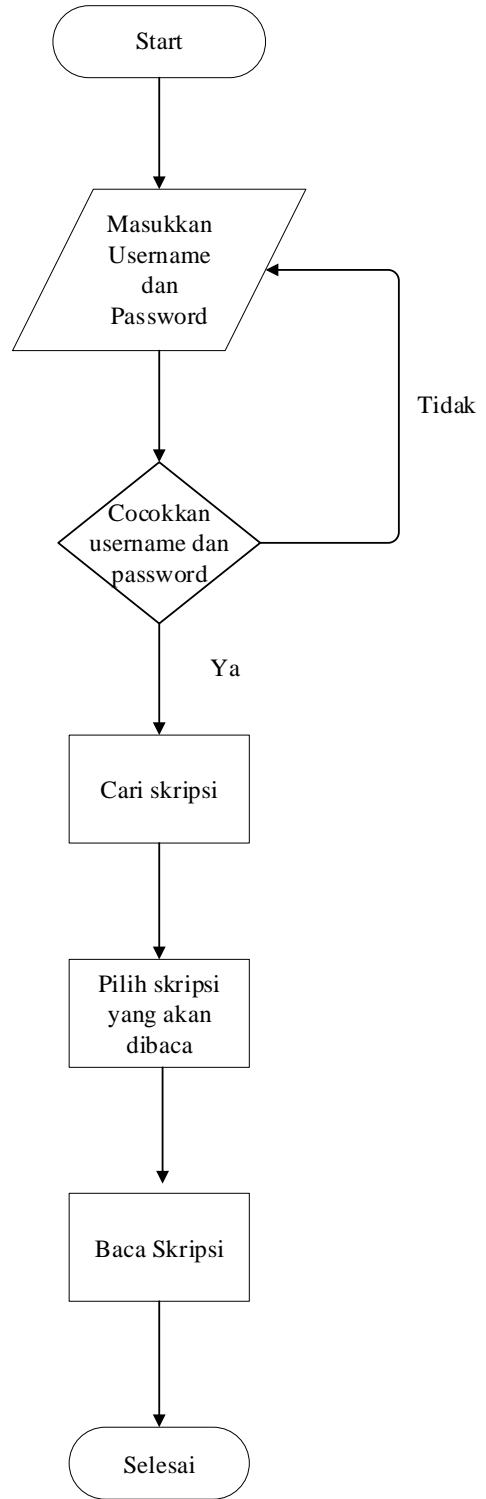

Gambar 3.2 Flowchart Aplikasi Skripsi Online

Pada Flowchart aplikasi diatas dapat kita lihat langkah-langkah tersebut dimulai dari start kemudian masukkan username dan password kemudian mencocokkan username dan juga password, jika salah, masukkan kembali username dan password, jika username dan password benar, kita dapat melanjutkan langkah selanjutnya yaitu pilih skripsi yang akan dibaca, kemudian baca skripsi, dan selesai.

\section{Hasil Pembahasan}

1. Hasil Tampilan Interface User Aplikasi Skripsi Online a) Halaman Home 


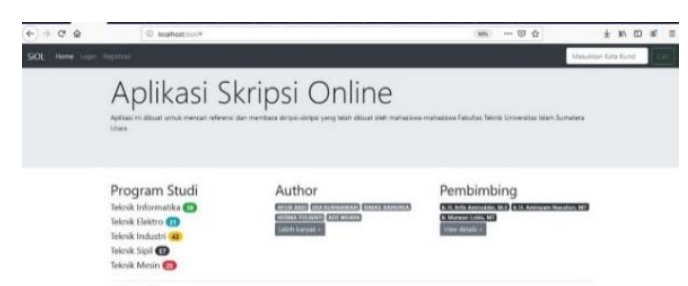

Gambar 5. Tampilan Home Pada Aplikasi Skripsi Online

Pada Tampilan ini pengunjung hanya dapat melihat berapa banyak skripsi yang ada dengan masing-masing prodi, nama-nama mahasiswa yang baru menyelesaikan skripsi, dan juga nama dosen pembimbing.

b) Halaman Login

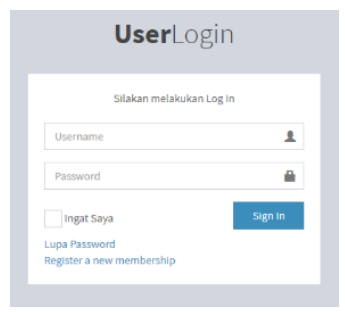

Gambar 6. Tampilan Login User dan Admin

Gambar diatas merupakan gambar tampilan login. Halaman tersebut digunakan untuk melakukan proses login admin dan user.

c) Halaman Admin

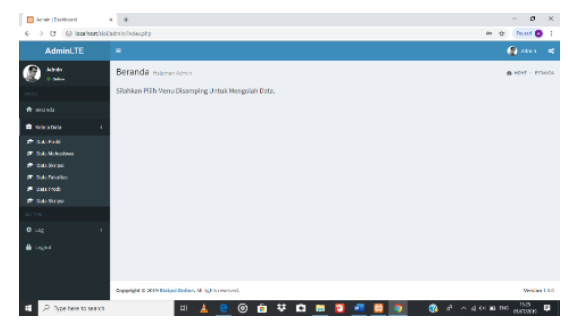

Gambar 7. Tampilan Halaman Home Admin

Pada halaman home admin, admin dapat melakukan:

- Mengakses data profil

- Mengakses data mahasiswa

- Mengakses data skripsi

- Mengakses data fakultas

- Mengakses data prodi

- Mengakses data skripsi 
d) Halaman Home user

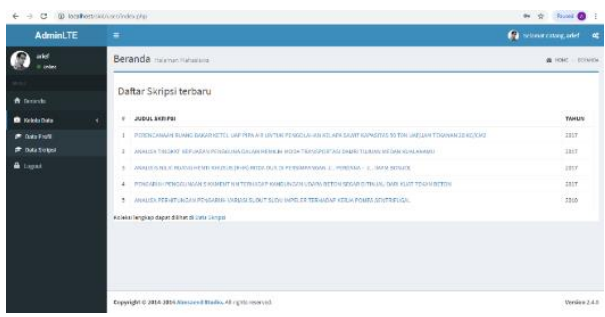

Gambar 8. Tampilan Halaman Home User

Pada halaman home atau beranda user, pengunjung dapat melihat skripsi yang terbaru. Pengunjung juga dapat mengakses data profil, dan juga data skripsi.

e) Tampilan Flipbook

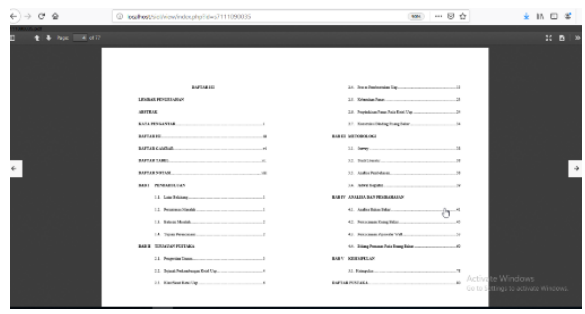

Gambar 9. Tampilan Flipbook

Pada Tampilan Flipbook pengunjung hanya bisa membaca isi skripsi dengan tampilan seperti membalikkan sebuah buku.

Kelebihan pada aplikasi skripsi online ini yaitu :

1. Dapat mempermudah mahasiswa dalam mencari referensi skripsi.

2. Dengan adanya tampilan Flipbook, tampilan skripsi menjadi lebih menarik.

Kekurangan pada Aplikasi Skripsi online ini yaitu :

1. Aplikasi ini sering lambat dijalankan, dikarenakan tampilan Flipbook yang memproses file pdf menjadi tampilan flipbook.

2. File yang diupload harus file pdf.

\section{Kesimpulan}

Setelah Aplikasi Skripsi Online ini dibuat maka diperoleh beberapa kesimpulan, antara lain :

1. Dengan menerapkan sistem algoritma pencarian String Matching ini pencarian data-data skripsi berdasarkan abstrak skripsi dapat dilakukan dengan mudah. 


\section{DAFTAR PUSTAKA}

1. Jogiyanto H.M. (2001). Analisa dan Desain Sistem Informasi. Edisi pertama. Yogyakarta: Andi Offset.

2. Sutarman.2003. Membangun Aplikasi Web PHP dan MySQL. Yokyakarta: Graha Ilmu

3. Hulbert, Jens. and Helger, Joakim Poromaa. 2007. "Seminar Course in AlgorithmsProject Report". [Online], Tersedia : https://www.slideshare.net/mukaninawi/sistempengukuran-tingkat-similaritas-dokumen-dengan-algoritma-rabinkarp-dan-enhancedconfix-stripping-stemmer?from_action=save [10 Mei 2019]

4. Rohi, Abdulloh, 2016. "Easy \& Simple - Web Programming", [Online], $\quad$ Tersedia https://books.google.co.id/books?id=E4tKDwAAQBAJ\&pg=PA1\&

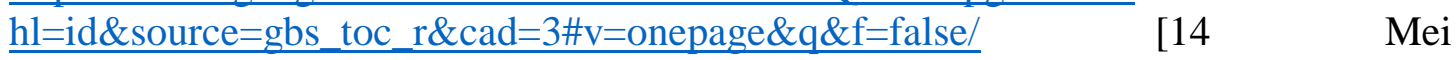
2019]

5. Masrur, Mukhamad. 2016. Pemrograman Web Dinamis Menggunakan Java Server Pages dengan Database Relasional MYSQL. Yogyakarta: C.V Andi Offset.[Online], Tersedia :

http://repository.usu.ac.id/bitstream/handle/123456789/68672/Chapter\%20II.pdf?sequ ence $=4 \&$ isAllowed $=y[20$ Juni 2019] 